\title{
Relationship between lichen species composition, secondary metabolites and soil pH, organic matter, and grain characteristics in Manitoba.
}

\begin{tabular}{|r|l|}
\hline Journal: & Botany \\
\hline Manuscript ID & cjb-2017-0176.R1 \\
\hline Manuscript Type: & Article \\
\hline Date Submitted by the Author: & 04-Dec-2017 \\
\hline $\begin{array}{r}\text { Complete List of Authors: } \\
\text { Is the invited manuscript for } \\
\text { consideration in a Special } \\
\text { Issue? : }\end{array}$ & $\begin{array}{l}\text { Zraik, Mohanad; University of Manitoba, Biological Sciences } \\
\text { Biercey-Normore, Michele; Memorial University of NL, Science and the } \\
\text { Environment }\end{array}$ \\
\hline Keyword: & $\begin{array}{l}\text { Cladonia, lichen species, organic matter, secondary metabolites, sand } \\
\text { particles }\end{array}$ \\
\hline & \multicolumn{2}{|c}{} \\
\hline
\end{tabular}

\section{SCHOLARONE ${ }^{\text {w }}$ \\ Manuscripts}


1 Relationship between lichen species composition, secondary metabolites and soil $\mathbf{p H}$,

2 organic matter, and grain characteristics in Manitoba

3 Mohanad Zraik, Tom Booth, and Michele D. Piercey-Normore.

4

6 Mohanad Zraik, Department of Biological Sciences, University of Manitoba, Winnipeg,

7 Manitoba, Canada, R3T 2N2; email: zraikm@myumanitoba.ca

9 Tom Booth, Department of Biological Sciences, University of Manitoba, Winnipeg, Manitoba,

10 Canada, R3T 2N2; email: thomas.booth@umanitoba.ca

12 Michele D. Piercey-Normore, Department of Biological Sciences, University of Manitoba,

13 Winnipeg, Manitoba, Canada, R3T 2N2; email: mpiercey-normore@grenfell.mun.ca

20 Corresponding author (and current affiliation): Michele D. Piercey-Normore, School of Science

21 and the Environment, Memorial University of Newfoundland (Grenfell campus), Corner Brook,

22 NL, A2H 5G4; phone: (709) 637-7166; email: mpiercey-normore@grenfell.mun.ca 
24 Abstract: Many lichen secondary metabolites have functions related to the environmental

25 conditions of lichen habitats but few studies have compared soil characteristics with lichen

26 species composition or their secondary products. The goal of this study was to investigate the

27 relationship between soil characteristics with lichen species composition and secondary

28 metabolites. Five locations were chosen in Manitoba, each with five sites (transect), and each

29 transect with five quadrats $(1 \mathrm{~m} \mathrm{x} 1 \mathrm{~m})$. All species were collected from each of the quadrats,

30 presence of secondary metabolites was determined by thin layer chromatography, and soil

31 characteristics were examined. The results revealed that round sand grains were significantly

32 higher in southeast Manitoba than other locations corresponding with a distinct species

33 composition. Angular grains were significantly higher in northern locations, corresponding to a

34 different group of species. Some of the significant relationships between soil characteristics and

35 secondary metabolites include correlations of atranorin with $\mathrm{pH}$, organic matter and sand

36 content; fumarprotocetraric acid with organic matter and sand content; and usnic acid with $\mathrm{pH}$

37 and organic matter. A better understanding of the role of lichens with respect to soil

38 characteristics will be important for improving soil stabilization in land reclamation.

42 Keywords: Cladonia, lichen species, organic matter, sand particles, secondary metabolites. 


\section{Introduction}

48 The effect of environmental conditions on individual lichen species has been shown through

49 studies where environmental variables were linked to morphological differences (Gilbert 1977;

50 Goffinet and Bayer 1997; Pintado et al. 1997; Baloch et al. 2010; Kotelko and Piercey-Normore

51 2010; Cornejo and Scheidegger 2013; Muggia et al. 2014). Some of these studies supported the

52 optimal defence theory (McKey 1974; Rhoades 1979; Asplund et al. 2010) where secondary

53 metabolite production was correlated with herbivory, and abiotic variables such as light

54 (McEvoy et al. 2006; Armaleo et al. 2008), pH (Fox and Howlett 2008; Timsina et al. 2013), and

55 humidity (Culberson and Armaleo 1992; Stocker Wörgötter 2001). However, few studies have

56 examined the relationship between substrate and the lichen phenotype or secondary metabolite

57 production (Brodo 1973; Gilbert 1977). Additionally, the substrate has been examined with

58 respect to water soluble nutrients available for lichen soil crusts (Fisher et al. 2014), substrate

59 moisture in an Alaskan tundra (Williams et al. 1978), and as an important source of nutrients by

60 fungal enzyme activity (Moiseeva 1961). The role of the soil in nutrient and moisture availability

61 corresponded with species distribution (Jun and Rozé 2005) and would be expected to depend to

62 some degree on the extent of direct contact between the soil and the lichen thallus. To our

63 knowledge, no study has examined the relationship between soil characteristics with lichen

64 species composition or secondary metabolite production.

Secondary metabolites produced by lichen-forming fungi comprise diverse groups of

66 metabolites (Elix and Stocker-Wörgötter 2008). A well-studied group includes the polyketides,

67 which are produced by the fungal partner in the acetyl-polymalonyl pathway. A large body of

68 literature is available on polyketide production in non-lichenized fungi (Keller and Hohn 1997;

69 Sanchez et al. 2010; Chen et al. 2014) and it is growing for the lichenized fungi (Stocker- 
70 Wörgötter 2001; 2008). While the biosynthesis of some polyketides from non-lichenized fungi is

71 being unravelled (e.g., Chiang et al. 2009; Campbell and Veraras 2010; Chiang et al. 2010;

72 Weissman 2015), knowledge of the biosynthesis of the many unique compounds from lichenized

73 fungi is lagging behind, with some progress made in usnic acid (Abdel-Hameed et al. 2016).

74 Better knowledge of the conditions required for culturing the lichen fungus to induce polyketide

75 production would facilitate progress on these studies. Since lichen polyketides are produced in

76 nature, it might be expected that a better understanding of the natural conditions, including the

77 substrate, would facilitate culturing. The potential for the application of polyketides in industry

78 or health related fields has increased the interest in this group of compounds.

Polyketide production has been hypothesized to be associated with slow growth of the

80 fungus. For example, it has been suggested that overwintering stages, reproduction, and other life

81 stages may cause slow growth (Bu'Lock 1961; Calvo et al. 2001; Timsina et al. 2013).

82 Polyketide production may also be regulated by the carbon-nutrient balance hypothesis (Bryant

83 et al. 1983; Hyvarinen et al. 2003), which is based on the concept that an imbalance of nutrients

84 will promote production of carbon-based secondary metabolites. The hypothesis suggests that

85 when a plant or lichen is growing in nutrient-poor conditions, the carbon may be shunted into

86 carbon-based secondary metabolites such as polyketides. When the plant or lichen is growing in

87 nutrient rich and balanced conditions the carbon may be used in thallus growth rather than

88 production of secondary metabolites. However, the hypothesis is controversial because it

89 represents a complex model with many interacting variables (Koricheva 2002). For example, soil

90 features and community structure may influence the nutrients available to lichens and their

91 growth rates; therefore, they may indirectly influence production of secondary metabolites in

92 lichens. 
Some lichens are extreme stress tolerators and able to adapt to harsh conditions on sandy

94 soils in areas where plants are absent, reducing the competition on lichens and allowing them to

95 dominate in these locations (Botting and Fredeen 2006). Jun and Rozé (2005) found a significant

96 relationship between the edaphic parameters (soil $\mathrm{pH}$, water content, nutrient content) and the

97 distribution of species for lichens and bryophytes in the sand dunes of the French Atlantic coast.

98 The content of organic material and carbon also affected the occurrence of some species in sandy

99 areas. For example, the occurrence of some species of Cladonia, such as Cladonia arbuscula, C.

100 mitis, and C. portentosa, are favoured by the acidification of the substrate (James et al. 1977),

101 while differences in the occurrence of C. pocillium and C. pyxidata corresponded with the $\mathrm{pH}$ of

102 the soil on which they were growing (Kotelko and Piercey-Normore 2010).

103 The goal of this study was to investigate the relationship among secondary metabolites,

104 lichen species composition and soil characteristics in five locations in Manitoba. The soil

105 characteristics were examined to determine which characteristics had the largest influence on

106 species and secondary metabolite occurrence.

108 Methods:

109 Experimental design and sample collection

110 Field collections were made in five different locations in northern and southern Manitoba (Fig.

111 1), and were focused in areas with sandy soils (Table 1). The five locations have a continental

112 climate and contain soils which vary in underlying geology (Table 1; Fig. 1; Geological Survey

113 of Canada 2006). Samples of all species of lichens were collected from each of five quadrats (1

$114 \mathrm{~m} \times 1 \mathrm{~m}$ ) in each of five sites (transects) in each of five locations (125 quadrats in total). The

115 quadrats were placed every $5 \mathrm{~m}$ along a $25 \mathrm{~m}$ transect within each site and the upper right corner 
116 of the quadrat was placed over a lichen thallus. The percent ground cover of the species recorded

117 as guilds and other biotic (vascular plants, bryophytes, and lichens by general categories) and

118 abiotic (bare rock, exposed soil, and vegetative debris such as twigs, cones, leaves, etc.) factors

119 were recorded by visual estimation to the nearest $5 \%$ using a $25 \mathrm{~cm} \times 25 \mathrm{~cm}$ grid placed within

120 the quadrat for estimating coverage. Percent canopy cover was estimated using the same grid and

121 held directly above the quadrat to estimate the amount of light. Specimens were air dried and

122 returned to the lab for identification using Ahti (2000), Brodo et al. (2001), Hinds and Hinds

123 (2007), and Kowalewska et al. (2008). In order to determine the secondary metabolites present,

124 thin layer chromatography (TLC) was performed on all specimens using solvent A (toluene 185

$125 \mathrm{~mL}$ : dioxane $45 \mathrm{~mL}$ : glacial acetic acid $5 \mathrm{~mL}$ ) (Orange et al. 2001). Briefly, about $200 \mathrm{uL}$ of

126 acetone was applied to the crushed thallus samples which were left soaking for 20 minutes.

127 Acetone extracts were applied to silica-coated glass plates, immersed within solvent A in a TLC

128 tank until the solvent front reached the top of the plate. After drying, the plates were observed

129 under long (365 nm) and short (255 nm) wave UV light, sprayed with 10\% sulphuric acid, and

130 heated at $80^{\circ} \mathrm{C}$ for 20 minutes. Standard secondary metabolites as positive controls were

131 prepared from herbarium specimens that had the chemicals previously identified for comparison.

132 Known Rf classes and further spot comparisons were made with characteristics in Orange et al.

133 (2001). Frequency of occurrence for secondary metabolites was recorded.

\section{Soil characteristics}

136 Two soil samples (multiple representative samples and a single bulk sample) were collected from

137 each of the 125 quadrats (25 in each of 5 locations). Multiple samples were collected from

138 different places in the quadrat and placed within clean plastic bags (about $1 \mathrm{~kg}$ ) to represent the 
139 surface soil in the quadrat (0 to $7 \mathrm{~cm}$ depth) and to determine soil characteristics. Bulk density

140 samples were collected from the center of the quadrat using a standard bulk density cylinder

141 (7.62 cm height X $7.62 \mathrm{~cm}$ diameter). Organic matter was calculated as loss of carbon on

142 ignition by burning the soil samples at $650^{\circ} \mathrm{F}$ for 18 hours using a muffle furnace

143 (Barnstead/Thermolyne). Percentage of the main soil components (sand, silt and clay), and

144 gravel as an additional soil component, were determined by sieving the soil samples with

145 different soil sieves using the Canadian standard sieve sizes (Fisherbrand U.S. Standard Brass

146 Test Sieves; sieve number 10 (2.00 mm opening) to collect the silt and clay grains, sieve

147 numbers $35(0.50 \mathrm{~mm}$ opening) and $100(0.149 \mathrm{~mm}$ opening $)$ to collect the fine and coarse sand,

148 respectively, and sieve number 200 (0.074 $\mathrm{mm}$ opening) for rocks and pebbles). Shape of the

149 sand grains was also determined and divided into two main categories (angular and rounded)

150 (Arculus et al. 2015) for 125 samples from each of 125 quadrats using a dissecting microscope

151 (Leica MZ 6) at 10× magnification. The grain shape was determined from a soil analysis kit

152 (Forestry Suppliers, Inc. MI). A distilled water mixture with soil was prepared for measuring the

$153 \mathrm{pH}$ of the soil using a $\mathrm{pH}$ meter (VWR sypHony SB70P). The $\mathrm{pH}$ measures were performed

154 according to standard methods (Benton and Jones 1999).

\section{Statistical analyses}

157 Principle Coordinates Analysis (PCoA; Legendre and Legendre 1998) was used to test the

158 similarities among lichen species composition using the R package "vegan" (Oksanen et al.

159 2015). The studied species were scored as present or absent. To examine whether soil

160 characteristics influenced secondary metabolite frequency and species compositions, redundancy

161 analyses were performed using the "rda" function in the R package "vegan". Monte Carlo 
162 permutation tests were performed to test the significance of redundancy analysis. The frequency

163 of occurrence of secondary metabolites was tested by recording the number of quadrats in which

164 each secondary metabolite was found. The soil $\mathrm{pH}$ levels were divided into two groups: high

165 acidic soil (pH ranging from 4.2 to 5.7) and neutral to slightly acidic soil (pH ranging from 6.1 to

166 7.4) to compare frequency of secondary metabolites and lichen species. Significance tests for soil

167 characteristics, biotic and abiotic factors, species frequency, and secondary metabolite frequency

168 were performed using ANOVA by the JMP program 12.1.0 (64 bit), and comparison of the

169 means was done by Tukey HSD. The frequency of secondary metabolites and species occurrence

170 (number of quadrats in which each secondary metabolite or species was detected) was examined

171 with location as a categorical variable. To test the relationship between soil features (organic

172 matter, $\mathrm{pH}$, and sand content) and occurrence of secondary metabolites as continuous variables, a

173 correlation was performed using the JMP program 12.1.1. Statistical analyses were performed

174 with the R program (R Core Development Team 2013), using a significance level of $\alpha=0.05$

175 unless otherwise indicated.

\section{Results}

178 Soil characteristics for each of the five locations are described in Table 2. Gravel content was

179 highest in the Sandilands Provincial Forest $(18.2 \pm 3.2 \%)$. The sand content in Spruce Woods

180 Provincial Park $(92.6 \pm 0.5 \%)$ was significantly higher than that of the other four locations. The

181 finest sand grains were in the Sandilands Provincial Forest and Spruce Woods Provincial Park;

182 and the coarsest sand grains were in in North Star and Athapap. The percent of rounded sand

183 grains was significantly higher in Sandilands Provincial Forest $(82.2 \pm 2.1 \%)$ than other

184 locations while angular grains were more abundant in North Star than other locations $(84.9 \pm$ 
185

186

187

$2.2 \%$ though not significantly different from Sherridan). The highest Round/Angular (R/A) ratio was in Sandilands Provincial Forest. Clay and silt levels were significantly higher in Athapap $(35.8 \pm 2.0 \%)$ than in other locations. Organic matter was significantly higher in Sherridon and Athapap than the other locations $(28.6 \pm 5.7 \%$ and $27.9 \pm 5.6 \%$, respectively). The $\mathrm{pH}$ level was significantly higher in Spruce Woods Provincial Park than in North Star but there was no difference between the other three locations (Table 2).

The percent canopy and ground covers for the quadrats in each location are shown in Table 3. Briefly, Sherridon, and Athapap had a significantly higher percentage of canopy cover compared to Sandilands Provincial Forest and Spruce Woods Provincial Park. North Star showed a significantly higher percentage of ground cover of lichens than Athapap and Sandilands (Table 3). Bryophyte ground cover was significantly higher in Athapap. The cup-forming lichens were significantly higher in Spruce Woods Provincial Park (except North Star), while mat-forming lichens were significantly higher in Sherridon than other locations. Stereocaulon and crustose lichens were significantly higher in North Star than the other locations (except Sherridan), the red-fruited lichens were significantly higher in Athapap, but the foliose lichens showed no significant differences among locations. Other factors analysed included vegetative debris, which was high in Sherridan, exposed soil, which was high in Sandilands Provincial Forest, and bare rock, which was high in Sherridan and North Star.

Forty-six lichen species are reported in this study with greater than $10 \%$ frequency of occurrence (Table 4). Four species, Cladonia arbuscula, C. chlorophaea, C. gracilis ssp. turbinata, and C. pyxidata were the most frequently occurring species being present in 21 or 22 out of 25 total sites (transects) and were present in all five locations. Three species (Cladonia humilis, C. magyarica, and C. sulphurina) were found in one of the five locations (Table 4). 
209 locations are shown in Table 5. Zeorin, barbatic acid, and usnic acid were significantly high in

210 Sherridon and North Star. Squamatic acid and thamnolic acid were significantly high in North

211 Star. The presence of atranorin was significantly high in Spruce Woods Provincial Park.

212 Fumarprotocetraric acid and perlatolic acid were recorded in high frequency in all the five

213 locations and there were no significant differences among them.

214 The relationship between location and each of the soil characteristics is shown in Fig. 2.

215 In this PCoA, the horizontal axis explains $51.4 \%$ of the variation in the data, and the vertical axis

216 accounts for an additional 21.6\%. Spruce Woods Provincial Park clustered at the positive end of

217 the horizontal axis with higher sand content and fine sand, while Athapap, North Star, and

218 Sherridon clustered at the negative end of the horizontal axis. Sandilands Provincial Forest

219 clustered at the positive end of the horizontal axis with rounded sand grains. The PCoA showed

220 three main groups (Sandilands Provincial Forest, North Star, and Spruce Woods Provincial Park)

221 which were separated based on the soil characteristics (Fig. 2). Athapap and Sherridan had more

222 variable soil characteristics.

223 A highly significant relationship between the secondary metabolites and the soil

224 characteristics is shown by a Redundancy Analysis (Monte Carlo permutation test, $p=0.001$ )

225 (Fig. 3). The RDA axis 1 accounted for $62.2 \%$ of the variation in the data and axis 2 accounted

226 for an additional $22.8 \%$ of the variation. Some of the trends show that fumarprotocetraric acid

227 and atranorin were more commonly produced when lichens were growing in sandy fine soils.

228 Grayanic acid, thamnolic acid and merochlorophaeic acid were weakly associated with more

229 neutral pH levels (Fig. 3). Usnic acid, zeorin, and barbatic acid were associated with angular 
230 sand grains (Fig. 3). The sand content was negatively correlated with organic matter (Pearson's

231 product-moment correlation $r=-0.89 \% p=0.001)$.

A significant relationship was found between species and soil characteristics (Fig. 4). The

233 RDA axis 1 accounts for $44.81 \%$ of the variation and axis 2 accounts for an additional $19.93 \%$ of

234 the variation in the data. The trends show that Peltigera rufescens was associated with round

235 sand grains while Cladonia deformis, C. phyllophora, C. stellaris, Stereocaulon tomentosum, and

236 Vulpicida pinastri were more associated with the angular sand grains. It also suggested that $C$.

237 cariosa is associated with soil $\mathrm{pH}$ levels and C. humilis and C. magyarica are associated with

238 fine sand and total amount of sand (Fig. 4).

239 The correlation between soil characteristics and secondary metabolites showed strong

240 relationships. There were strong negative correlations between zeorin, usnic acid, barbatic acid

241 and squamatic acid with $\mathrm{pH}$ of the soil but the correlation between atranorin and $\mathrm{pH}$ was strongly

242 positive (Table 6). The correlation with organic matter was strongly positive with zeorin and

243 usnic acid, but it was strongly negative with atranorin and fumarprotocetraric acid. The

244 correlations between percent sand content and each of atranorin and fumarprotocetraric acid

245 were strongly positive (Table 6).

246 The correlation between soil characteristics and species occurrence also showed strong

247 relationships (Table 7). Some species (C. deformis, C. amaurocraea, C. gracilis spp. turbinata,

248 C. stellaris, Sterocaulon tomentosum, and Vulpicida pinistri) showed a strong negative

249 relationship with $\mathrm{pH}$. A strong positive relationship was present between two species (C. humilis,

250 C. magyarica) and the percent sand content in soil (Table 7). 


\section{Discussion}

254 Soil characteristics may explain some species distributions

255 The significant differences among the five locations were explained by differences in the soil

256 characteristics and partially by species composition. This finding suggests that some species may

257 not rely on the substrate for nutrients and moisture and have a wide tolerance for substrate

258 characteristics while other species may be linked to soil characteristics. For example, Peltigera

259 rufescens, Cladonia cariosa, C. humilis, C. scabruiscula, and C. magyarica segregated with

260 rounded sand grains (Fig. 2 and Table 2). Furthermore, Arctoparmelia centrifuga, Stereocaulon

261 tomentosum, C. deformis, C. stellaris, C. uncialis and C. amaurocraea correlated more strongly

262 with angular sand grains. The angular shape of the sand grains may minimize the spaces between

263 sand grains by fitting together but the round shape may allow for more space between grains and

264 therefore more water and air movement between grains (Lipiec et al. 2016). The shape of sand

265 grains has been shown to affect the compaction, compressibility and shear stress of soils and

266 therefore also the aeration, water holding capacity, and temperature regulation (Horn 2011; de

267 Bono and McDowell 2015). The thick mat of rhizines diagnostic of $P$. rufescens and the

268 persistent basal squamules in C. cariosa, C. humilis, and C. magyarica would help to stabilize

269 sand better than tall podetia with disintegrating basal squamules such as Cladonia gracilis ssp.

270 turbinata, C. cornuta, C. amaurocraea or C. uncialis. This hypothesis would need further

271 testing.

272 Cladonia phyllophora and C. gracilis ssp. turbinata are common boreal species (Brodo et

273 al. 2001) which look very similar and were both present in all five locations suggesting they may

274 be tolerant of a wide range of soil conditions. They may receive their nutrients from a

275 combination of the soil (especially when they are young with squamules attached directly to the 
276 soil) and the atmosphere (especially as they age as the squamules disintegrate). Cladonia

277 phyllophora has no cortex near the top of a tall podetium and a black mottled base whereas $C$.

278 gracilis ssp. turbinata has a smooth cortex giving it an olive color throughout the length of a tall

279 podetium. The similar morphological features in these species, where both species produce tall

280 podetia and the primary basal squamules disintegrate with time, suggests that the direct

281 connection with the soil by the primary squamules may be severed after the podetia have been

282 produced. It would stand to reason that after squamule disintegration, the colony of tall podetia

283 must rely predominantly on an atmospheric source of nutrients and moisture or splash from the

284 substrate or adjacent mosses. Few studies have been conducted on the source of nutrients;

285 however, the substrate has been shown to be correlated with lichen growth for water soluble

286 nutrients in lichen soil crusts (Fisher et al. 2014), in an Alaskan tundra (Williams et al. 1978),

287 and an important source of nutrients through enzyme activity (Moiseeva 1961). While early

288 squamule growth of these species may penetrate the soil particles and offer some stabilization

289 properties for disturbed soils, the later podetial growth may be more independent of the soil

290 characteristics.

291 High levels of organic matter may reduce the $\mathrm{pH}$ level of the soil, making the soil more

292 acidic (Sparks 2003). Acidic soils seem to be more favourable for C. amaurocraea, C.

293 arbuscula, and $C$. deformis, while C. cariosa, C. pocillium and C. magyarica are known to grow

294 in calcareous substrata (Culberson 1969; Wetherbee 1969; Brodo et al. 2001). While C. pocillum

295 was limited to the less acidic soils in Athapap and Spruce Woods Provincial Park (Table 4), $C$.

296 pyxidata was more widespread showing no correlation with $\mathrm{pH}$ (Table 7) suggesting that acidic

297 substrata may have been available or the species can tolerate less acidic soils. Species such as $C$.

298 chlorophaea and C. rangiferina were found in both acidic and neutral soils suggesting they may 
299 also be more tolerant of $\mathrm{pH}$ changes in the substrata than some other species. While some

300 chemotypes of the C. chlorophaea complex prefer only calcareous substrata such as $C$.

301 cryptochlorophara, C. grayi, C. pocillium (Gilbert 1977; Piercey-Normore 2006) and C. cariosa

302 (Culberson 1969), Cladonia merochlorophaea and C. pyxidata, are known to grow on acidic

303 substrates (Brodo et al. 2001). Patches of soil or substrata with higher pH levels even in a

304 location characterized by low $\mathrm{pH}$ levels may explain the presence of these species. For example,

305 C. merochlorophaea was reported to grow directly on moss over calcareous soil where the moss

306 provided the acidic substrate for the lichen (Piercey-Normore 2005; 2006; 2008).

Soil characteristics and the carbon-nutrient balance hypothesis

309 The carbon-nutrient balance (CNB) hypothesis (Bryant et al. 1983; Hyvarinen et al. 2003) was

310 not supported by the results of this study. Lichens such as Cladonia arbuscula and C. rangiferina

311 are mat-forming lichens since they grow acropetally forming a carpet of upright thalli in which

312 the crustose primary thallus disintegrates over time and the upright thallus often grows well

313 above the soil layer. The formation of this mass of vegetative thallus suggests that more carbon

314 was needed to produce a larger mass of thallus (Crittenden 2000). If the CNB hypothesis was

315 supported, the larger mass would have corresponded with fewer secondary metabolites, but this

316 was not the case. Some species with this growth form were more abundant in locations with high

317 organic matter in the soil such as C. uncialis, C. stellaris, and C. amaurocraea, which were

318 predominantly in Sherridan and North Star. However, other species such as C. arbuscula and C.

319 rangiferina were present in 4 or 5 of the locations suggesting they could tolerate a wider range of

320 organic matter in the soil. Only C. arbuscula, of these mat-forming species, was present in

321 Athapap, which also had significantly higher levels of organic matter than other locations. The 
322 larger amount of carbon in the soil with more organic matter may allow for more vegetative

323 growth in these mat-forming species, but all species produced similar numbers of carbon based

324 secondary metabolites. While the numbers of secondary metabolites in this study showed no

325 support for the carbon-nutrient balance hypothesis, it may be hypothesized that the quantity of

326 each secondary metabolite may show more support for the hypothesis.

328 Soil features may influence the occurrence of some secondary metabolites

329 The distribution of usnic acid and atranorin, but not fumarprotocetraric acid, may be explained

330 by soil characteristics. The presence of usnic acid was significantly higher in the more acidic

331 sites of Sherridon and North Star (Table 6), where usnic acid may help the lichen tolerate acidic

332 substrata (Hauck et al. 2009a). Usnic acid may also serve as an anti-herbivorous substance

333 (Nimis and Skert 2006) or as a sun-screening metabolite (Hauck 2008). Lichen species that

334 produce usnic acid were more dominant on acidic substrata such as Cladonia amaurocraea, $C$.

335 arbuscula, C. cristatella C. deformis, C. stellaris, and C. uncialis (Table 3; Hauck 2009b;

336 Doering et al. 2016). On the other hand, production of atranorin and fumarprotocetraric acid may

337 also be affected by sand acidity levels. The presence of atranorin in lichen species in the less

338 acidic sites, such as Spruce Woods Provincial Park and to a lesser extent Athapap (Table 5), may

339 reflect the higher $\mathrm{pH}$ levels in the habitat rather than light or humidity levels in the environment.

340 If light or humidity played a role in the distribution of thalli containing atranorin, the canopy

341 cover should influence their distribution. However, Spruce Woods Provincial Park had the

342 lowest canopy cover and Athapap had the highest canopy cover (Table 3), which does not

343 support the light regulating properties of atranorin to make light available for the photobiont 
344 (Melo et al. 2011). However, shrub or herbaceous canopy layers may have played a role in the

345 amount of light reaching the lichens and therefore the presence of atranorin in the lichen thallus.

346 The $\mathrm{pH}$ of the soil alone does not seem to influence the type of secondary metabolite

347 produced by lichens in this study. Species containing fumarprotocetraric acid were reported to be

348 more common in acidic sites such as on peat soils (Purvis et al. 1992) or on the bark of conifers

349 (Gauslaa et al. 1998) and the production of fumarprotocetraric acid was thought to increase the

350 tolerance of lichens for acidic substrates (Hauck 2008; Hauck 2009a). However,

351 fumarprotocetraric acid was present in all five locations with no significant difference in

352 frequency of occurrence (Table 5). Culberson et al. (1977) reported a correlation with the amount

353 of fumarprotocetraric acid production in the C. chlorophaea group with distance from the ocean

354 in North Carolina. The frequency of occurrence of 13 other fumarprotocetraric acid-containing 355 species varied among locations with different $\mathrm{pH}$ levels suggesting that $\mathrm{pH}$ was not affecting the

356 production of this compound.

358 Conclusion

359 The physical and chemical components of the soil substrate have been previously assumed to be

360 important factors in species assemblages but this is one of the first studies to closely examine soil

361 characteristics relative to species and secondary metabolite occurrence. The finding that many of

362 the species, with some exceptions, were not influenced by soil characteristics, supports the

363 concept that lichens receive their nutrients and moisture from atmospheric sources. However, the

364 few species that showed relationships with soil, highlight valuable implications for stabilizing

365 soils and provide further hypotheses for testing. The carbon-nutrient balance hypothesis was not

366 supported in this study since all species produced some secondary metabolites even when carbon 
367 was present in the soil. However, the quantification, rather than occurrence, of the secondary

368 metabolites in lichen species may be used in future studies to test the carbon-nutrient balance

369 hypothesis more directly. The sand content and shape of the soil particles seemed to have the

370 greatest effect on species composition and the occurrence of some secondary metabolites in this

371 study, but the correlations provide insights that need to be further tested. These novel findings

372 are partially exploratory and draw upon relationships among variables that have not previously

373 been examined.

\section{Acknowledgements}

376 The authors thank J. Doering and C. Deduke for assistance in the field and statistical analysis.

377 This project was supported by a Faculty of Science award to MZ, GETS to MPN for MZ, and an

378 NSERC Discovery Grant to MPN, and collection permits from Manitoba Conservation and Parks 379 Canada.

\section{References}

383 Abdel-Hameed, M., Bertrand, R.L., Piercey-Normore, M.D., and Sorensen, J.L. 2016. Putative 384 identification of the usnic acid biosynthetic gene cluster by de novo whole-genome 385 sequencing of a lichen-forming fungus. Fungal Biol. 120(3): 306-316.

386 Ahti, T. 2000. Cladoniaceae, Flora Neotropica Monograph 78. New York Botanical Garden, $387 \quad$ New York.

388 Arculus, R.J., Ishizuka, O., Bogus, K., and the Expedition 351 Scientists. 2015. Izu-BoninMariana arc origins: continental crust formation at an intra-oceanic arc: foundation, 
inception, and early evolution. International Ocean Discovery Program Preliminary Report, 351. http://dx.doi.org/10.14379/iodp.pr.351.2015

Armaleo, D., Zhang, Y., and Cheung, S. 2008. Light might regulate divergently depside and depsidone accumulation in the lichen Parmotrema hypotropum by affecting thallus temperature and water potential. Mycologia, 100: 565-576.

Asplund, J., Solhaug, K., and Gauslaa, Y. 2010. Optimal defense: snails avoid reproductive parts of the lichen Lobaria scrobiculata due to internal defense allocation. Ecology, 91: 31003105.

August, P.R., Tang, L., Yoon, Y.J., Ning, S., Muller, R., Yu, T.W., Taylor, M., Hoffmann, D., Kim, C.G., Zhang, X., Hutchinson, C.R., and Floss, H.G. 1998. Biosynthesis of the ansamycin antibiotic rifamycin: deductions from the molecular analysis of the rif biosynthetic gene cluster of Amycolatopsis mediterranei s699. Chem. Biol. 5: 69-79.

Baloch, E., Lücking, R., Lumbsch, H.T., and Wedin, M. 2010. Major clades and phylogenetic relationships between lichenized and non-lichenized lineages in Ostropales (Ascomycota: Lecanoromycetes). Taxon, 59(5): 1483-1494.

Benton, J., and Jones, J.R. 1999. Soil Analysis Handbook of Reference Methods. CRC Press, NY.

Botting, R.S., and Fredeen, A.L. 2006. Contrasting terrestrial lichen, liverwort, and moss diversity between old-growth and young second-growth forest on two soil textures in central British Columbia. Can. J. Bot. 84: 120-132.

Brodo I. M.1973. Substrate ecology. In The Lichens. Edited by V. Ahmadjian, and M.E. Hale M.E. Academic Press, New York and London. pp. 401-441.

Brodo, I., Sharnoff, S.D., and Sharnoff, S. 2001. Lichens of North America. Yale University 
Press, New Haven and London.

414 Bryant, J.P., Chapin, F.S., and Klein, D.R. 1983. Carbon-nutrient balance of boreal plants in relation to vertebrate herbivory. Oikos, 40: 357-368.

416 Bu'Lock, J.D. 1961. Intermediary metabolism and antibiotic synthesis. Advances in Applied 417 Microbiology, 3: 293-342.

418 Calvo, A.M., Wilson, R.A., and Keller, N.A. 2001. Relationship between secondary metabolism 419 and fungal development. Microbiol. Mol. Biol. Rev. 66: 447-459.

420 Campbell, C.D., and Vereras, J.C. 2010. Biosynthesis of lovastatin and related metabolites 421 formed by fungal iterative PKS enzymes. Bioploymers, 93: 755-763.

422 Chen, G., Wang, H., and Pei, Y.J. 2014. Secondary metabolites from marine-derived 423 microorganisms. Asian Nat. Prod. Res. 16: 105-122.

424 Chiang, Y.M., Oakley, B.R., Keller, N.P., and Wang, C.C.C. 2010. Unraveling polyketide synthesis in members of the genus Aspergillus. Appl. Microbiol. Biotechnol. 86: 1719-

427 Chiang, Y.M., Szewczyk, E., Davidson, A.D., Keller, N., Oakley, B.R., and Wang, C.C.C. 2009.

428 A gene cluster containing two fungal polyketide synthases encodes the biosynthetic pathway for a polyketide, Asperfuranone, in Aspergillus. J. Am. Chem. Soc. 131: 29652970.

431 Cornejo, C., and Scheidegger, C. 2013. New morphological aspects of cephalodium formation in the lichen Lobaria pulmonaria (Lecanorales, Ascomycota). Lichenologist, 45(1): 77-87.

433 Crittenden, P.D. 2000. Aspects of the ecology of mat-forming lichens. Rangifer, 20(3): 127-139. 434 Culberson, W.L. 1969. The chemistry and systematics of some species of the Cladonia cariosa 435 group in North America. Bryologist, 72: 377-386. 
436 Culberson, C.F., Culberson, W.L., and Arwood, D.A. 1977. Physiography and

437 fumarprotocetraric acid production in the Cladonia chlorophaea group in North Carolina.

$438 \quad$ Bryologist, 80: 71-75.

439 Culberson, C.F., and Armaleo, D. 1992. Induction of a complete secondary-product pathway in a $440 \quad$ cultured lichen fungus. Exp. Mycol. 16: 53-63.

441 De Bono, J.P., McDowell, G.R. 2015. An insight into the yielding and normal compression 442 of sand with irregularly-shaped grains using DEM. Powder Technol. 271: 270-277.

443 Doering, J., Deduke, C., and Piercey-Normore M.D. 2016. Variation in lichen species

444 assemblages and secondary metabolites surrounding Stereocaulon species in boreal forest 445 of Northwestern Manitoba. Evansia, 33(2): 70-79.

446 Elix, J. A., Stocker-Wörgötter, E. 2008. Biochemistry and secondary metabolites. In Lichen Biology, 2nd edition. Edited by T.H. Nash III. Cambridge University Press, Cambridge,

449 Fischer, T., Gypser, S., Subbotina, M., and Veste, M. 2014. Synergic hydraulic and nutritional pp. 104-133.

452 Fox, E.M., and Howlett, B.J. 2008. Secondary metabolism: regulation and role in fungal biology. 453 Curr. Opin. Microbiol. 11: 481-487.

454 Gauslaa, Y., Ohlson, M., and Rolstad, J. 1998. Fine-scale distribution of the epiphytic lichen Usnea longissima on two even-aged neighbouring Picea abies trees. J. Veg. Sci. 9: 95102.

457 Gilbert, O.L. 1977. Fungal plasticity in Cladonia pocillum. Lichenologist, 9: 172-173. 
458

459

460

461

462

463

464

465

466

467

468

469

470

471

472

473

474

475

476

477

478

479

480

Goffinet, B., and Bayer, R.J. 1997. Characterization of mycobionts of photomorph pairs in the Peltigeraceae (lichenized Ascomycetes) based on internal transcribed spacer sequences of the nucler ribosomal DNA. Fungal Genet. Biol. 21: 228-237.

Hauck, M. 2008. Susceptibility to acidic precipitation contributes to the decline of the terricolous lichens Cetraria aculeata and Cetraria islandica in central Europe. Environ. Pollut. 152: 731-735.

Hauck, M., Jürgens, S.R., Willenbruch, S., Huneck, S., and Leuschner, C. 2009a. Dissociation and metal-binding characteristics of yellow lichen substances suggest a relationship with site preferences of lichens. Ann. Bot. 103: 13-22.

Hauck, M., Jürgens, S.R., Huneck, S., and Leuschner, C. 2009b. High acidity tolerance in lichens with fumarprotocetraric, perlatolic or thamnolic acids is correlated with low pKal values of these lichen substances. Environ. Pollut. 157: 2776-2780.

Huck, B., and Whiteway, D. 2013. In Search of Canada's Ancient Heartland. Heartland Associates. pp. 65-67.

Hinds, W.J., and Hinds, L.P. 2007. Machrolichens of New England. The New York Botanical Garden Press. USA.

Horn, R. 2011. Friction phenomena in soils. In Encyclopedia of Agrophysics. Edited by J. Gliński, J. Horabik, and J. Lipiec. Springer, Dordrecht, Heidelberg, London, New York, pp. 316-318.

Hyvarinen, M., Walter, B., and Koopmann, R. 2003. Impact of fertilization on phenol content and growth rate of Cladina stellaris: a test of the carbon-nutrient balance hypothesis. Oecologia, 134: 176-181.

James, P.W., Hawksworth, D.L., and Rose, F. 1977. Lichen communities in the British Isles: a 
preliminary conspectus. Academic Press, London, p. 296-409.

482

483

484

485

486

487

Jun, R., and Rozé, F. 2005. Monitoring Bryophytes and lichens dynamics in sand dunes: example on the French Atlantic coast. In Dunes and Esturaries, 2005. Proceedings of the International Conference on Nature Restoration Practices in European Coastal Habitats, Koksijde, Belgium. 19-23 September, 2005. Edited by J.L. Herrier, J. Mees, A. Salman, J. Seys, H. Van Nieuwenhuyse, and I. Dobbelaere. VLIZ Special Publication 19, pp. 291-313.

Keller, N.P., and Hohn, T.M. 1997. Metabolic pathway gene clusters in filamentous fungi. Fungal Genetics and Biology, 21: 17-29.

Koricheva, J. 2002. The carbon-nutrient balance hypothesis is dead: long live the carbon-nutrient balance hypothesis? Oikos, 98: 3.

Kotelko, R., and Piercey-Normore, M.D. 2010. Cladonia pyxidata and C. pocillum; genetic evidence to regard them as conspecific. Mycologia, 102: 534-545.

Kowalewska, A., Kukwa, M., Ostrowska, I., Jabłońska, A., Oset, M., and Szok, J. 2008. The lichens of the Cladonia pyxidata-chlorophaea group and allied species in Poland. Herzogia, 21: 61-78.

Legendre, P., and Legendre, L. 1998. Numerical Ecology, 2nd English edition. Developments in Environmental Modelling No. 20. Elsevier Science, Philadelphia, PA.

Lipiec, J., Siczek, A., Sochan, A., and Bieganowski, A. 2016. Effect of sand grain shape on root and shoot growth of wheat seedlings. Geoderma, 265: 1-5.

McKey, D. 1974. Adaptive patterns in alkaloid physiology. Am. Nat. 108:

$305-320$. 
503

504

505

506

507

508

509

510

511

512

513

514

515

516

517

518

519

520

521

522

523

524

525

McEvoy, M., Nybakken, L., Solhaug, K.A., and Gauslaa, Y. 2006. UV triggers the synthesis of the widely distributed secondary lichen compound usnic acid. Mycological Progress, 5: $221-229$.

Melo, M.G.D., Araújo, A.A.S., Serafini, M.R., Carvalho, L.F., Bezerra, M.S., Ramos, C.S., Bonjardim, L.R., Albuquerque-Júnior, R.L.C., Lima, J.T., Siqueira, R.S., Fortes, V.S., Fonseca, M.J.V., Quintans-Júnior, L.J. 2011. Anti-inflammatory and toxicity studies of atranorin extracted from Cladina kalbii Ahti in rodents. Brazilian Journal of Pharmaceutical Sciences, 47(4): 861-872.

Moiseeva, E.N. 1961. Biochemical properties of lichens and their practical importance. Akademia Nauk SSSR. Botanischeski Institut im. Edited by V.L. Komarova, Moscow. 82 pp.

Muggia, L.S., Pérez-Ortega, A., Fryday, T., and Spribille, M.G. 2014. Global assessment of genetic variation and phenotypic plasticity in the lichen-forming species Tephromela atra. Fungal Diversity, 64(1): 233-251.

Nimis, P.L., and Skert, N. 2006. Lichen chemistry and selective grazing by the coleopteran Lasioderma serricorne. Environ. Exp. Bot. 55: 175-182.

Oksanen, J., Blanchet, F.G., Kindt, R., Legendre, P., Minchin, P.R., O’Hara, R.B., Simpson, G.L., Solymos, P., Stevens, M., Henry, H., and Wagner, H. 2015. Vegan: Community Ecology Package. Available from: http://cran.rproject.org/web/packages/vegan/vegan.pdf.

Orange, A., James, P.W., and White, F.J. 2001. Microchemical methods for the identification of lichens. British Lichen Society.

Piercey-Normore, M.D. 2003. A field survey of the genus Cladonia (Ascomycotina) in 
Manitoba. Mycotaxon, 86: 233-247.

527 Piercey-Normore, M.D. 2005. Lichens from the Hudson Bay Lowlands: Northeastern coastal regions of Wapusk National Park in Manitoba. Can. J. Bot. 83: 1029-1038.

529 Piercey-Normore, M.D. 2006. Lichens from the Hudson Bay Lowlands: Diversity in the southeastern peatlands of Wapusk National Park, Manitoba. Can. J. Bot. 84: 1781-1793.

531 Piercey-Normore, M.D. 2008. A Survey of Lichens and Bryophytes in White Spruce, Picea glauca. Can. Field-Nat. 122(3): 199-204.

533 Pintado, A., Valladeres, F., and Sancho, L.G. 1997. Exploring phenotypic plasticity in the lichen Ramalina capitata: Morphology, water relations, and chlorophyll content in north and Flora of Great Britain and Ireland. The British Lichen Society. London

Rhoades, D.F. 1979. Evolution of plant chemical defense against herbivores. In south facing populations. Annals of Botany, 80: 345-353.

Purvis, W.O., Coppins, B.J., Hawksworth, D.L., James, P.W., and Moor, D.M. 1992. The Lichen Herbivores: their interaction with secondary plant metabolites. Edited by G.A. Rosenthal

541 R Development Core Team. 2013. R: A language and environment for statistical computing [Computer program]. Vienna: R Foundation for Statistical Computing.

543 Sanchez, J.F., Chiang, Y.M., Szewczyk, E., Davidson, A.D., Ahuja, M., Oakley, C.E., Bok, J.W., Keller, N., Oakley, B.R., and Wang, C.C. 2010. Molecular genetic analysis of the

546 Sparks, D. 2003. Environmental Soil Chemistry. Academic Press. London. UK.

547 Stocker-Wörgötter, E. 2001. Experimental studies of the lichen symbiosis: DNA analyses, 
differentiation and secondary chemistry of selected mycobionts, artificial resynthesis of two- and tripartite symbioses. Symbiosis, 30: 207-227.

550 Stocker-Wörgötter, E. 2008. Metabolic diversity of lichen-forming ascomycetous fungi: culturing, polyketide and shikimate metabolite production, and PKS genes. Natural Products Reports, 25: 188-200.

553 Timsina, B.A., Sorensen, J.L., and Weihrauch, D. 2013. Effect of aposymbiotic conditions on 554 colony growth and secondary metabolite production in the lichen-forming fungus Ramalina dilacerata. Fungal Biol. 117(11-12): 731-43.

556 Weissman, K.J. 2015. Uncovering the structures of modular polyketide synthases. Natural $557 \quad$ Products Reports, 32: 436-453.

558 Williams, M.E., Rudolph. E.D., Schofield, E.A., and Prasher, D.C. 1978. The role of lichens in 559 the structure, productivity, and mineral cycling of the wet coastal Alaskan tundra. In Vegetation and Production Ecology of an Alaskan Arctic Tundra, Ecological 
Table 1. General characteristics (rows) of the locations (columns) of collection sites (transects) including latitude and longitude, prevalent parent bedrock material, maximum and minimum yearly temperatures, and location descriptions with dominant vegetation.

573

\begin{tabular}{|c|c|c|c|c|c|}
\hline Characteristics & Sherridon Road & North Star Road & Athapap Road & $\begin{array}{l}\text { Spruce Woods } \\
\text { Provincial Park }\end{array}$ & $\begin{array}{l}\text { Sandilands } \\
\text { Provincial } \\
\text { Forest }\end{array}$ \\
\hline Latitude and & N54 $77^{\prime} 72.9 ”$ & N54 69’75.4" & N54 $51^{\prime} 58.8^{\prime \prime}$ & $\mathrm{N} 49^{\circ} 43^{\prime} 45.4^{\prime \prime}$ & N49 $44^{\prime} 31.9^{\prime \prime}$ \\
\hline longitude & $\mathrm{W} 101^{\circ} 47^{\prime} 37.5^{\prime \prime}$ & $\mathrm{W} 101^{\circ} 68^{\prime} 12.3 "$ & $\mathrm{~W} 101^{\circ} 53^{\prime} 19^{\prime \prime}$ & W99 $17 ’ 29.2^{\prime \prime}$ & W96 39' $22.8^{\prime \prime}$ \\
\hline $\begin{array}{l}\text { Parent } \\
\text { material }\end{array}$ & Granite & Gneiss & $\begin{array}{l}\text { Calcaric } \\
\text { regosols }\end{array}$ & Aeolian regosols & $\begin{array}{l}\text { Glacial till } \\
\text { regosols }\end{array}$ \\
\hline $\begin{array}{l}\text { Temp }\left({ }^{\circ} \mathrm{C}\right) \\
\max / \min \end{array}$ & $23.8 /-24.7$ & $23.8 /-24.7$ & $24 /-28.9$ & $26 /-24.3$ & $26 /-23.2$ \\
\hline $\begin{array}{l}\text { Location } \\
\text { description } \\
\text { and dominant } \\
\text { plant species }\end{array}$ & $\begin{array}{l}\text { Precambrian } \\
\text { Shield. Patches of } \\
\text { soil in crevices of } \\
\text { bedrock and } \\
\text { among outcrops. } \\
\text { Aspen, birch, } \\
\text { white spruce, Jack } \\
\text { pine, willow and } \\
\text { alder. }\end{array}$ & $\begin{array}{l}\text { Precambrian } \\
\text { Shield. Patches of } \\
\text { soil in crevices of } \\
\text { bedrock and } \\
\text { among outcrops. } \\
\text { Aspen, birch, } \\
\text { white spruce, Jack } \\
\text { pine, willow and } \\
\text { alder. }\end{array}$ & $\begin{array}{l}\text { Shallow regosol } \\
\text { on limestone } \\
\text { bedrock. Mixed } \\
\text { forest with } \\
\text { aspen, white } \\
\text { spruce, fir, white } \\
\text { birch, and alder. }\end{array}$ & $\begin{array}{l}\text { Active and } \\
\text { stabilized sand } \\
\text { dunes. Grasses } \\
\text { and bluffs of } \\
\text { white spruce, } \\
\text { aspen, and } \\
\text { juniper in } \\
\text { depressions. } \\
\text { Oaks on high } \\
\text { ridges. }\end{array}$ & $\begin{array}{l}\text { Rolling forest } \\
\text { and sandy till. } \\
\text { Jack pine, } \\
\text { aspen, and white } \\
\text { spruce } \\
\text { interspersed } \\
\text { with low lying } \\
\text { black spruce } \\
\text { stands. }\end{array}$ \\
\hline
\end{tabular}


597

Table 2. Soil characteristics in five sites (transects) across five locations in this study. Values are mean \pm standard error derived from five one- $\mathrm{m}^{2}$ quadrats from each of five transects for each of five locations. Soil characteristics include gravel, sand, fine sand, course sand, rounded grain, angular grain, organic matter (in percentage of fraction of total weight), ratios of round to angular grains (R/A), and $\mathrm{pH}$ levels. $\mathrm{R} / \mathrm{A}$ ratios are calculated as mean \pm standard error over the individual values of $\mathrm{R} / \mathrm{A}$ for the 25 plots sampled in each of the locations. Bold numbers represent significant values at the given probability levels in the first column for each soil characteristic. Upper case letters indicate significant differences within rows at $p<0.05$ using Tukey's HSD test.

\begin{tabular}{|c|c|c|c|c|c|}
\hline Soil Characteristics & $\begin{array}{l}\text { Sherridon } \\
\text { Road }\end{array}$ & $\begin{array}{l}\text { North Star } \\
\text { Road }\end{array}$ & $\begin{array}{l}\text { Athapap } \\
\text { Road }\end{array}$ & $\begin{array}{l}\text { Spruce } \\
\text { Woods } \\
\text { Provincial } \\
\text { Park }\end{array}$ & $\begin{array}{l}\text { Sandilands } \\
\text { Provincial } \\
\text { Forest }\end{array}$ \\
\hline Gravel $(p=0.0001)$ & $11.7 \pm 1.7^{\mathrm{AB}}$ & $9.8 \pm 0.9^{\mathrm{B}}$ & $8.9 \pm 1.1^{\mathrm{B}}$ & $6.4 \pm 0.5^{\mathrm{B}}$ & $18.2 \pm 3.2^{\mathrm{A}}$ \\
\hline Sand $(p<0.0001)$ & $65.8 \pm 3.9^{\mathrm{C}}$ & $60.2 \pm 1.6^{\mathrm{CD}}$ & $54.8 \pm 2.6^{\mathrm{D}}$ & $92.6 \pm 0.5^{A}$ & $78.7 \pm 3.2^{\mathrm{B}}$ \\
\hline Fine sand $(p<0.0001)$ & $61.6 \pm 3.8^{\mathrm{B}}$ & $39.2 \pm 1.4^{\mathrm{C}}$ & $46.3 \pm 0.8^{\mathrm{C}}$ & $89.3 \pm 1.4^{\mathrm{A}}$ & $87.1 \pm 1.7^{\mathrm{A}}$ \\
\hline Coarse sand $(p<0.0001)$ & $38.4 \pm 3.8^{\mathrm{B}}$ & $60.2 \pm 1.4^{\mathrm{A}}$ & $53.6 \pm 0.8^{\mathrm{A}}$ & $10.7 \pm 1.4^{\mathrm{C}}$ & $12.9 \pm 1.7^{\mathrm{C}}$ \\
\hline Rounded grain $(\mathrm{R})(p<0.0001)$ & $28.7 \pm 4.0^{\mathrm{D}}$ & $15.2 \pm 2.1^{\mathrm{E}}$ & $57.6 \pm 3.3^{\mathrm{B}}$ & $40.0 \pm 1.2^{\mathrm{C}}$ & $82.8 \pm 2.1^{\mathrm{A}}$ \\
\hline Angular grain $(\mathrm{A})(p<0.0001)$ & $71.3 \pm 5.4^{\mathrm{AB}}$ & $84.9 \pm 2.2^{A}$ & $42.5 \pm 4.6^{\mathrm{C}}$ & $60.1 \pm 1.0^{\mathrm{B}}$ & $17.1 \pm 3.4^{\mathrm{D}}$ \\
\hline $\mathrm{R} / \mathrm{A}$ ratio $(p<0.0001)$ & $0.62 \pm 0.2^{\mathrm{B}}$ & $0.19 \pm 0.03^{\mathrm{B}}$ & $1.77 \pm 0.2^{\mathrm{B}}$ & $0.68 \pm 0.03^{\mathrm{B}}$ & $8.22 \pm 1.6^{\mathrm{A}}$ \\
\hline Clay and silt $(p<0.0001)$ & $18.2 \pm 3.4^{\mathrm{C}}$ & $27.3 \pm 1.7^{\mathrm{B}}$ & $35.8 \pm 2.0^{A}$ & $0.8 \pm 0.1^{\mathrm{D}}$ & $2.7 \pm 0.4^{\mathrm{D}}$ \\
\hline Organic matter $(p=0.001)$ & $28.6 \pm 5.7^{\mathrm{A}}$ & $17.9 \pm 3.5^{\mathrm{B}}$ & $27.9 \pm 5.6^{\mathrm{A}}$ & $1.7 \pm 0.3^{\mathrm{C}}$ & $5.4 \pm 1.1^{\mathrm{C}}$ \\
\hline $\mathrm{pH}$ level $(p=0.001)$ & $5.54 \pm 0.4^{\mathrm{BC}}$ & $4.98 \pm 0.3^{\mathrm{C}}$ & $6.62 \pm 0.1^{\mathrm{AB}}$ & $7.00 \pm 0.2^{\mathrm{A}}$ & $6.38 \pm 0.2^{\mathrm{AB}}$ \\
\hline
\end{tabular}


601 Table 3. Mean percentage of quadrat cover including canopy, vascular plants, vegetative debris, 602 bryophytes, lichens (total and by general categories), unvegetated soil, and bare rock over five 603 one square meter quadrats for each of five sites (transects) in each of the locations. Bold numbers 604 represent significant values at the given probabilities for each cover characteristic. Upper case 605 letters indicate significant differences within rows at $p<0.05$ using Tukey's HSD test.

606

\begin{tabular}{|c|c|c|c|c|c|}
\hline Location & $\begin{array}{l}\text { Sherridon } \\
\text { Road }\end{array}$ & $\begin{array}{l}\text { North Star } \\
\text { Road }\end{array}$ & $\begin{array}{l}\text { Athapap } \\
\text { Road }\end{array}$ & $\begin{array}{l}\text { Spruce } \\
\text { Woods } \\
\text { Provincial } \\
\text { Park }\end{array}$ & $\begin{array}{l}\text { Sandilands } \\
\text { Provincial } \\
\text { Forest }\end{array}$ \\
\hline Canopy cover $(p<0.0001)$ & $36 \pm 7.2^{\mathrm{A}}$ & $28 \pm 5.7^{\mathrm{AB}}$ & $34.4 \pm 6.1^{\mathrm{A}}$ & $3.8 \pm 2.5^{\mathrm{C}}$ & $11.6 \pm 4^{\mathrm{BC}}$ \\
\hline Vascular plants $(p=0.1000)$ & $4.9 \pm 1.4^{\mathrm{A}}$ & $15.1 \pm 3.8^{\mathrm{A}}$ & $17.1 \pm 3.3^{\mathrm{A}}$ & $10.6 \pm 3^{\mathrm{A}}$ & $12.6 \pm 4.3^{\mathrm{A}}$ \\
\hline Vegetative debris $(p=0.0030)$ & $26.5 \pm 5.8^{A}$ & $14.4 \pm 4.1^{\mathrm{AB}}$ & $11.8 \pm 2.4^{\mathrm{B}}$ & $7.0 \pm 1.9^{\mathrm{B}}$ & $11.2 \pm 2.5^{\mathrm{B}}$ \\
\hline Bryophytes $(p<0.0010)$ & $10.0 \pm 2.4^{\mathrm{B}}$ & $2.0 \pm 0.6^{\mathrm{B}}$ & $29.0 \pm 5.4^{\mathrm{A}}$ & $6.4 \pm 2.4^{\mathrm{B}}$ & $7.3 \pm 1.7^{\mathrm{B}}$ \\
\hline Lichens total $(p=0.0070)$ & $49.8 \pm 4.8^{\mathrm{AB}}$ & $56.64 \pm 5.9^{A}$ & $35.8 \pm 4.9^{\mathrm{B}}$ & $46.3 \pm 4.3^{\mathrm{AB}}$ & $34 \pm 4.5^{\mathrm{B}}$ \\
\hline Cup lichens $(p<0.0001)$ & $18.7 \pm 5^{\mathrm{B}}$ & $30.6 \pm 5^{\mathrm{AB}}$ & $16.4 \pm 4.5^{\mathrm{B}}$ & $44.3 \pm 4.4^{\mathrm{A}}$ & $20.4 \pm 3.3^{\mathrm{B}}$ \\
\hline Red-fruited lichens $(p<0.0001)$ & $0.28 \pm 0.09^{\mathrm{B}}$ & $0.44 \pm 0.1^{\mathrm{B}}$ & $14.1 \pm 4.4^{\mathrm{A}}$ & $0.2 \pm 0.08^{\mathrm{B}}$ & $0.42 \pm 0.9^{\mathrm{B}}$ \\
\hline Crustose lichens $(p<0.0001)$ & $0.00 \pm^{\mathrm{B}}$ & $13.8 \pm 3.7^{\mathrm{A}}$ & $1.1 \pm 0.6^{\mathrm{B}}$ & $0.00^{\mathrm{B}}$ & $0.00^{\mathrm{B}}$ \\
\hline Stereocaulon $(p<0.0001)$ & $1.1 \pm 0.6^{\mathrm{AB}}$ & $3.4 \pm 1.3^{\mathrm{A}}$ & $0.2 \pm 0.13^{\mathrm{B}}$ & $0.00^{\mathrm{B}}$ & $0.00^{\mathrm{B}}$ \\
\hline Mat-forming lichens $(p<0.0001)$ & $29.3 \pm 4.8^{\mathrm{A}}$ & $6.7 \pm 2.3^{\mathrm{B}}$ & $1.3 \pm 0.6^{\mathrm{B}}$ & $1.3 \pm 1^{\mathrm{B}}$ & $11.2 \pm 3.6^{\mathrm{B}}$ \\
\hline Foliose lichens $(p=0.052)$ & $0.16 \pm 0.07^{\mathrm{A}}$ & $1.3 \pm 0.67^{\mathrm{A}}$ & $2.7 \pm 1^{\mathrm{A}}$ & $0.5 \pm 0.4^{\mathrm{A}}$ & $2 \pm 0.8^{\mathrm{A}}$ \\
\hline Exposed soil $(p=0.0005)$ & $0.12 \pm 0.07^{\mathrm{B}}$ & $1.8 \pm 0.8^{\mathrm{B}}$ & $2.6 \pm 1.2^{\mathrm{B}}$ & $4.6 \pm 1.2^{\mathrm{AB}}$ & $10.3 \pm 3.1^{\mathrm{A}}$ \\
\hline Bare rock $(p=0.0011)$ & $5.4 \pm 0.6^{\mathrm{A}}$ & $5.1 \pm 1.4^{\mathrm{A}}$ & $0.72 \pm 0.6^{\mathrm{AB}}$ & $0.00^{\mathrm{B}}$ & $0.00^{\mathrm{B}}$ \\
\hline
\end{tabular}


613 Table 4. Frequency of occurrence (means \pm standard error (SE)) of lichen species ${ }^{1}$ over 25 one614 square meter quadrats per site (transect) in each of the five locations. Bold numbers are 615 significant at the given probabilities for each species as shown in the first column. Upper case 616 letters indicate significant differences within rows at $p<0.05$ using Tukey's HSD test.

617

\begin{tabular}{|c|c|c|c|c|c|}
\hline Location & Sherridon & North Star & Athapap & $\begin{array}{l}\text { Spruce } \\
\text { Woods }\end{array}$ & Sandilands \\
\hline Arctoparmelia centrifuga $(p<0.0001)$ & $0.00^{\mathrm{C}}$ & $0.64 \pm 0.09^{A}$ & $0.36 \pm 0.09^{\mathrm{B}}$ & $0.000^{\mathrm{C}}$ & $0.00^{\mathrm{C}}$ \\
\hline Cladonia amaurocraea $(p<0.0001)$ & $0.40 \pm 0.10^{\mathrm{A}}$ & $0.24 \pm 0.08^{\mathrm{A}}$ & $0.00^{\mathrm{B}}$ & $0.00^{\mathrm{B}}$ & $0.00^{\mathrm{B}}$ \\
\hline Cladonia arbuscula $(p<0.0001)$ & $1.00 \pm 0.0^{A}$ & $0.64 \pm 0.09^{\mathrm{B}}$ & $0.44 \pm 0.1^{\mathrm{BC}}$ & $0.16 \pm 0.08^{\mathrm{C}}$ & $0.52 \pm 0.10^{\mathrm{BC}}$ \\
\hline Cladonia cariosa $(p<0.0001)$ & $0.00^{\mathrm{B}}$ & $0.00^{\mathrm{B}}$ & $0.56 \pm 0.10^{A}$ & $0.36 \pm 0.09^{A}$ & $0.04 \pm 0.04^{\mathrm{B}}$ \\
\hline Cladonia chlorophaea $(p=0.0196)$ & $\mathbf{0 . 5 2 \pm 0 . 1 0 ^ { \mathrm { AB } }}$ & $0.68 \pm 0.09^{A}$ & $0.68 \pm 0.09^{A}$ & $0.28 \pm 0.09^{\mathrm{B}}$ & $0.44 \pm 0.10^{\mathrm{AB}}$ \\
\hline Cladonia cornuta $(p=0.0450)$ & $0.48 \pm 0.10^{\mathrm{A}}$ & $0.28 \pm 0.09^{\mathrm{AB}}$ & $0.12 \pm 0.06^{\mathrm{B}}$ & $0.32 \pm 0.09^{\mathrm{AB}}$ & $0.28 \pm 0.09^{\mathrm{AB}}$ \\
\hline Cladonia crispata $(p=0.0650)$ & $0.12 \pm 0.06^{\mathrm{AB}}$ & $0.16 \pm 0.07^{\mathrm{A}}$ & $0.00^{\mathrm{A}}$ & $0.04 \pm 0.04^{\mathrm{A}}$ & $0.00^{\mathrm{A}}$ \\
\hline Cladonia cristatella $(p=0.0010)$ & $0.24 \pm 0.08^{\mathrm{AB}}$ & $0.44 \pm 0.10^{\mathrm{A}}$ & $0.04 \pm 0.04^{\mathrm{A}}$ & $0.04 \pm 0.04^{\mathrm{B}}$ & $0.28 \pm 0.09^{\mathrm{AB}}$ \\
\hline Cladonia decorticata $(p=0.0494)$ & $0.00^{\mathrm{A}}$ & $0.04 \pm 0.04^{\mathrm{A}}$ & $0.00^{\mathrm{A}}$ & $0.12 \pm 0.07^{\mathrm{A}}$ & $0.04 \pm 0.04^{\mathrm{A}}$ \\
\hline Cladonia deformis $(p<0.0001)$ & $0.40 \pm 0.10^{\mathrm{A}}$ & $0.56 \pm 0.10^{A}$ & $0.00^{\mathrm{B}}$ & $0.00^{\mathrm{B}}$ & $0.00^{\mathrm{B}}$ \\
\hline $\begin{array}{l}\text { Cladonia gracilis spp. turbinata } \\
(p<0.0001)\end{array}$ & $0.76 \pm 0.08^{A}$ & $0.68 \pm 0.09^{A}$ & $0.52 \pm 0.10^{A}$ & $0.12 \pm 0.06^{\mathrm{B}}$ & $0.48 \pm 0.10^{A}$ \\
\hline Cladonia grayi $(p=0.3144)$ & $0.12 \pm 0.06^{\mathrm{A}}$ & $0.04 \pm 0.04^{\mathrm{A}}$ & $0.00^{\mathrm{A}}$ & $0.04 \pm 0.04^{\mathrm{A}}$ & $0.12 \pm 0.06^{\mathrm{A}}$ \\
\hline Cladonia humilis $(p<0.0001)$ & $0.00^{\mathrm{B}}$ & $0.00^{\mathrm{B}}$ & $0.00^{\mathrm{B}}$ & $0.44 \pm 0.10^{A}$ & $0.000^{\mathrm{B}}$ \\
\hline Cladonia magyarica $(p<0.0001)$ & $0.00^{\mathrm{B}}$ & $0.00^{\mathrm{B}}$ & $0.00^{\mathrm{B}}$ & $0.96 \pm 0.04^{\mathrm{A}}$ & $0.000^{\mathrm{B}}$ \\
\hline $\begin{array}{l}\text { Cladonia merochlorophaea } \\
(p=0.038)\end{array}$ & $0.16 \pm 0.07^{\mathrm{A}}$ & $0.00^{\mathrm{A}}$ & $0.00^{\mathrm{A}}$ & $0.00^{\mathrm{A}}$ & $0.12 \pm 0.07^{\mathrm{A}}$ \\
\hline Cladonia multiformis $(p=0.0008)$ & $0.00^{\mathrm{B}}$ & $0.08 \pm 0.05^{\mathrm{B}}$ & $0.16 \pm 0.07^{\mathrm{AB}}$ & $0.00^{\mathrm{B}}$ & $0.32 \pm 0.09^{\mathrm{A}}$ \\
\hline Cladonia phyllophora $(p=0.0331)$ & $0.20 \pm 0.08^{\mathrm{AB}}$ & $0.16 \pm 0.07^{\mathrm{AB}}$ & $0.08 \pm 0.05^{\mathrm{B}}$ & $0.04 \pm 0.04^{\mathrm{B}}$ & $0.28 \pm 0.09^{A}$ \\
\hline Cladonia pocillum $(p=0.0660)$ & $0.00^{\mathrm{A}}$ & $0.00^{\mathrm{A}}$ & $0.04 \pm 0.04^{\mathrm{A}}$ & $0.12 \pm 0.07^{\mathrm{A}}$ & $0.00^{\mathrm{A}}$ \\
\hline Cladonia pyxidata $(p=0.0004)$ & $0.16 \pm 0.07^{\mathrm{B}}$ & $0.64 \pm 0.09^{A}$ & $0.60 \pm 0.1^{\mathrm{A}}$ & $0.36 \pm 0.09^{\mathrm{AB}}$ & $0.68 \pm 0.09^{A}$ \\
\hline
\end{tabular}




\begin{tabular}{|c|c|c|c|c|c|}
\hline Cladonia rangiferina $(p<0.0001)$ & $0.44 \pm 0.10^{A}$ & $0.16 \pm 0.07^{\mathrm{ABC}}$ & $0.00^{\mathrm{C}}$ & $0.04 \pm 0.04^{\mathrm{BC}}$ & $0.32 \pm 0.09^{\mathrm{AB}}$ \\
\hline Cladonia scabruiscula $(p=0.0024)$ & $0.00^{\mathrm{B}}$ & $0.04 \pm 0.04^{\mathrm{AB}}$ & $0.04 \pm 0.04^{\mathrm{AB}}$ & $0.28 \pm 0.09^{A}$ & $0.24 \pm 0.08^{\mathrm{AB}}$ \\
\hline Cladonia stellaris $(p<0.0001)$ & $0.44 \pm 0.10^{A}$ & $0.28 \pm 0.09^{A}$ & $0.00^{\mathrm{B}}$ & $0.00^{\mathrm{B}}$ & $0.00^{\mathrm{B}}$ \\
\hline Cladonia stygia $(p=0.1876)$ & $0.12 \pm 0.10^{\mathrm{A}}$ & $0.04 \pm 0.06^{\mathrm{A}}$ & $0.00^{\mathrm{A}}$ & $0.00^{\mathrm{A}}$ & $0.04 \pm 0.04^{\mathrm{A}}$ \\
\hline Cladonia sulphurina $(p=0.0138)$ & $0.00^{\mathrm{B}}$ & $0.12 \pm 0.06^{A}$ & $0.00^{\mathrm{B}}$ & $0.00^{\mathrm{B}}$ & $0.00^{\mathrm{B}}$ \\
\hline Cladonia uncialis $(p<0.0001)$ & $0.40 \pm 0.10^{A}$ & $0.12 \pm 0.06^{\mathrm{B}}$ & $0.00^{\mathrm{B}}$ & $0.00^{\mathrm{B}}$ & $0.00^{\mathrm{B}}$ \\
\hline Cladonia verticillata $(p=0.0494)$ & $0.04 \pm 0.04^{\mathrm{A}}$ & $0.00^{\mathrm{A}}$ & $0.00^{\mathrm{A}}$ & $0.04 \pm 0.04^{\mathrm{A}}$ & $0.16 \pm 0.07^{\mathrm{A}}$ \\
\hline Peltigera rufescens $(p<0.0001)$ & $0.08 \pm 0.05^{\mathrm{B}}$ & $0.04 \pm 0.04^{\mathrm{B}}$ & $0.56 \pm 0.10^{A}$ & $0.20 \pm 0.08^{\mathrm{B}}$ & $\mathbf{0 .} 28 \pm 0.09^{\mathrm{AB}}$ \\
\hline Sterocaulon tomentosum $(p<0.0001)$ & $0.04 \pm 0.04^{\mathrm{B}}$ & $0.32 \pm 0.09^{A}$ & $0.00^{\mathrm{B}}$ & $0.000^{\mathrm{B}}$ & $0.00^{\mathrm{C}}$ \\
\hline Umbilicaria deusta $(p<0.0001)$ & $0.04 \pm 0.04^{\mathrm{B}}$ & $0.28 \pm 0.09^{A}$ & $0.00^{\mathrm{B}}$ & $0.000^{\mathrm{B}}$ & $0.00^{\mathrm{C}}$ \\
\hline Vulpicida pinistari $(p<0.0001)$ & $\mathbf{0 .} 28 \pm 0.09^{\mathrm{AB}}$ & $0.40 \pm 0.10^{\mathrm{A}}$ & $0.08 \pm 0.05^{\mathrm{BC}}$ & $0.00^{\mathrm{C}}$ & $0.00^{\mathrm{B}}$ \\
\hline $\begin{array}{l}\text { Xanthoparmelia cumberlandia } \\
(p=0.0365)\end{array}$ & $0.04 \pm 0.04^{\mathrm{AB}}$ & $0.20 \pm 0.08^{\mathrm{A}}$ & $0.04 \pm 0.04^{\mathrm{AB}}$ & $0.00^{\mathrm{B}}$ & $0.04 \pm 0.04^{\mathrm{C}}$ \\
\hline
\end{tabular}

$618{ }^{\mathrm{T}}$ Only those species with $>10 \%$ frequency of occurrence are included in the table. The species, 619 Cetraria islandica, Cladonia acuminata, C. borealis, C. botrytes, C. cenotea, C. coniocraea, C. 620 fimbriata, C. gracilis ssp. gracilis, C. mitis, C. pleurota, C. subulata, Nephroma helveticum, 621 Parmelia saxatilis, Sterocaulon grande, and U. muehlenbergii, were found at frequencies $<10 \%$ 622 and are not included in the table. 
Table 5. Frequency of occurrence (means \pm standard error (SE)) of secondary metabolites ${ }^{1}$ over 25 one-square meter quadrats per site (transect) for each of five locations in Manitoba. Bold numbers are significant at the given probabilities for each species as listed in the first column. Upper case letters indicate significant differences within rows at $p<0.05$ using Tukey's HSD 630 test.

631

\begin{tabular}{|c|c|c|c|c|c|}
\hline $\begin{array}{l}\text { Location } \\
\text { Lichen acids }\end{array}$ & $\begin{array}{l}\text { Sherridon } \\
\text { Mean } \pm \text { SE }\end{array}$ & $\begin{array}{l}\text { North Star } \\
\text { Mean } \pm \text { SE }\end{array}$ & $\begin{array}{l}\text { Athapap } \\
\text { Mean } \pm \text { SE }\end{array}$ & $\begin{array}{l}\text { Spruce } \\
\text { Woods } \\
\text { Mean } \pm \text { SE }\end{array}$ & $\begin{array}{l}\text { Sandilands } \\
\text { Mean } \pm \text { SE }\end{array}$ \\
\hline Zeorin $(p<0.0001)$ & $0.48 \pm 0.1^{\mathrm{A}}$ & $0.68 \pm 0.09^{A}$ & $0.00^{\mathrm{B}}$ & $0.00^{\mathrm{B}}$ & $0.00^{\mathrm{B}}$ \\
\hline Barbatic acid $(p<0.0001)$ & $0.52 \pm 0.1^{\mathrm{A}}$ & $0.48 \pm 0.1^{\mathrm{A}}$ & $0.04 \pm 0.04^{\mathrm{B}}$ & $0.04 \pm 0.04^{\mathrm{B}}$ & $0.32 \pm 0.09^{\mathrm{AB}}$ \\
\hline Usnic acid $(p<0.0001)$ & $0.96 \pm 0.04^{\mathrm{A}}$ & $0.92 \pm 0.05^{\mathrm{A}}$ & $0.2 \pm 0.08^{\mathrm{C}}$ & $0.2 \pm 0.08^{\mathrm{C}}$ & $0.6 \pm 0.1^{\mathrm{B}}$ \\
\hline Thamnolic acid $(p=0.0138)$ & $0.00^{\mathrm{B}}$ & $0.12 \pm 0.06^{\mathrm{A}}$ & $0.00^{\mathrm{B}}$ & $0.00^{\mathrm{B}}$ & $0.00^{\mathrm{B}}$ \\
\hline Squamatic acid $(p=0.0042)$ & $0.2 \pm 0.08^{\mathrm{AB}}$ & $0.28 \pm 0.09^{A}$ & $0.04 \pm 0.04^{\mathrm{B}}$ & $0.00^{\mathrm{B}}$ & $0.04 \pm 0.04^{\mathrm{B}}$ \\
\hline Perlatolic acid $(p=0.2757)$ & $0.16 \pm 0.07^{\mathrm{A}}$ & $0.24 \pm 0.08^{\mathrm{A}}$ & $0.04 \pm 0.04^{\mathrm{A}}$ & $0.16 \pm 0.07^{\mathrm{A}}$ & $0.08 \pm 0.07^{\mathrm{A}}$ \\
\hline $\begin{array}{l}\text { Fumarprotocetraric acid } \\
(p=0.2479)\end{array}$ & $1.00 \pm 0.00^{\mathrm{A}}$ & $0.92 \pm 0.05^{\mathrm{A}}$ & $0.96 \pm 0.04^{\mathrm{A}}$ & $1.00 \pm 0.00^{\mathrm{A}}$ & $1.00 \pm 0.00^{\mathrm{A}}$ \\
\hline Atranorin $(p<0.0001)$ & $0.36 \pm 0.08^{\mathrm{BC}}$ & $0.32 \pm 0.08^{\mathrm{C}}$ & $0.68 \pm 0.08^{\mathrm{AB}}$ & $0.96 \pm 0.08^{A}$ & $0.4 \pm 0.08^{\mathrm{BC}}$ \\
\hline Grayanic acid $(p=0.3144)$ & $0.12 \pm 0.06^{\mathrm{A}}$ & $0.04 \pm 0.04^{\mathrm{A}}$ & $0.00^{\mathrm{A}}$ & $0.04 \pm 0.04^{\mathrm{A}}$ & $0.12 \pm 0.06^{\mathrm{A}}$ \\
\hline $\begin{array}{l}\text { Merochlorophaeic acid } \\
(p=0.016)\end{array}$ & $0.16 \pm 0.07^{\mathrm{A}}$ & $0.00^{\mathrm{A}}$ & $0.00^{\mathrm{A}}$ & $0.04 \pm 0.04^{\mathrm{A}}$ & $0.2 \pm 0.08^{\mathrm{A}}$ \\
\hline
\end{tabular}
occurrence include didymic, gyrophoric, stictic, norstictic, psoromic, salazinic, pinastric, lobaric, alectoronic, and vulpinic acids and are not included in the table. 
643 Table 6: Pearson correlation between three main soil characteristics ( $\mathrm{pH}$, organic matter, and 644 sand content) and the number of occurrence of secondary metabolites (n). Bold values are 645 significant at $p<0.05$.

646

\begin{tabular}{|c|c|c|c|c|c|c|c|c|c|c|}
\hline \multirow[b]{2}{*}{$\begin{array}{l}\text { Secondary } \\
\text { metabolite }\end{array}$} & \multirow[b]{2}{*}{$n$} & \multicolumn{3}{|l|}{ pH } & \multicolumn{3}{|c|}{ Organic matter (\%) } & \multicolumn{3}{|c|}{ Sand content $(\%)$} \\
\hline & & $R^{2}$ & $F$ & $P$ & $R^{2}$ & $F$ & $P$ & $R^{2}$ & $F$ & $P$ \\
\hline Atranorin & 141 & 15.48 & 22.53 & $<0.0001$ & -7.30 & 9.63 & 0.002 & 11.58 & 16.10 & 0.0001 \\
\hline Barbatic acid & 36 & -14.11 & 20.21 & $<0.0001$ & 2.72 & 3.44 & 0.070 & $9.78 \mathrm{e}^{-5}$ & 0.01 & 0.910 \\
\hline $\begin{array}{l}\text { Fumarproto- } \\
\text { cetraric acid }\end{array}$ & 432 & 2.40 & 3.05 & 0.083 & -11.00 & 15.20 & 0.0002 & 10.30 & 14.18 & 0.0003 \\
\hline Grayanic acid & 8 & 0.58 & 0.72 & 0.390 & 1.30 & 1.60 & 0.210 & 2.99 & 3.79 & 0.054 \\
\hline $\begin{array}{l}\text { Merochloro- } \\
\text { phaeic acid }\end{array}$ & 13 & 0.07 & 0.09 & 0.760 & 0.27 & 0.34 & 0.560 & 0.01 & 0.02 & 0.890 \\
\hline Perlatolic acid & 20 & 1.50 & 1.88 & 0.170 & 0.07 & 0.09 & 0.760 & 0.07 & 0.09 & 0.760 \\
\hline Squamatic acid & 15 & -3.21 & 4.08 & 0.045 & 0.17 & 0.21 & 0.650 & 0.09 & 0.11 & 0.740 \\
\hline Thamnolic acid & 3 & 0.15 & 0.19 & 0.670 & 1.50 & 1.88 & 0.170 & 0.02 & 2.80 & 0.090 \\
\hline Usnic acid & 185 & -25.24 & 41.50 & $<0.0001$ & 3.60 & 4.67 & 0.032 & 2.40 & 3.04 & 0.080 \\
\hline Zeorin & 46 & -12.27 & 17.20 & $<0.0001$ & 3.30 & 4.19 & 0.042 & 0.42 & 0.52 & 0.470 \\
\hline
\end{tabular}


Table 7: Pearson correlation between three main soil characteristics ( $\mathrm{pH}$, organic matter, and sand content) and the frequency of occurrence of lichen species $(n)$. Bold values are significant at $p=0.05$.

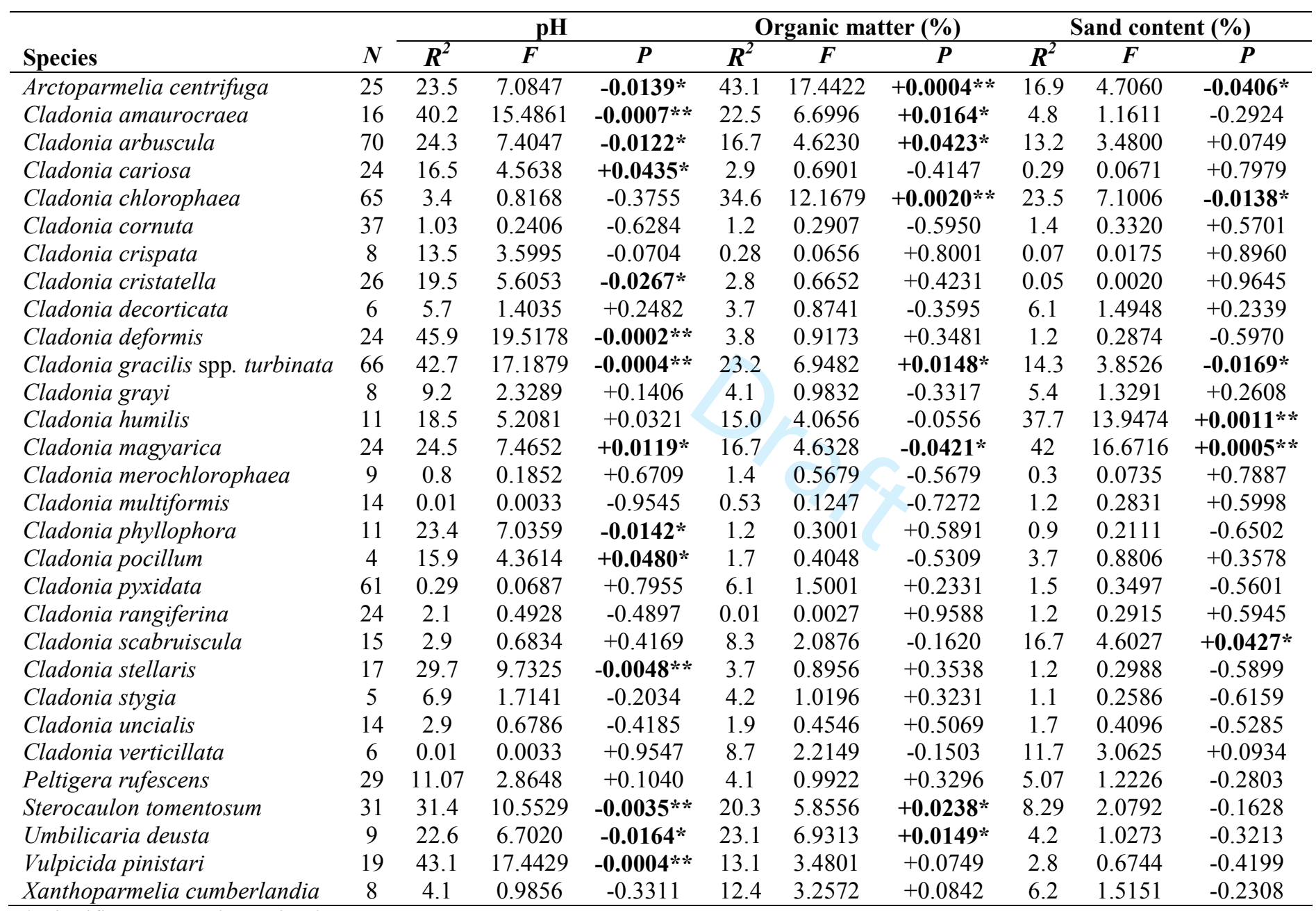

* Significance was determined at $p<0.05$

$* *$ Bonferonni correction of $p<0.0005(0.05 / \mathrm{X})$ 


\section{Figure captions}

Figure 1. Map of Manitoba, Canada, showing locations of collection sites (transects) in this study including the Sandilands Provincial Forest, Spruce Woods Provincial Park, Athapap Road, Sherridon Road, and North Star Road.

Figure 2. Principle Coordinates Analysis relating soil characteristics including gravel, sand (total, angular fraction, rounded fraction and grain size), silt and clay, organic matter, and $\mathrm{pH}$ in each of the five sites (transects) in each of five locations (NS = North Star Road; S = Sherridon Road; A = Athapap Road; SW = Spruce Woods Provincial Park; SA = Sandilands Provincial Forest). The horizontal axis explains $51.4 \%$ of the variation in the data and the vertical axis explains $21.6 \%$ of the variation.

Figure 3. Redundancy analysis of the Sherridon (S), North Star (NS), Athapap (A), Spruce Woods (SW), and Sandilands (SA) locations and percent frequencies of the secondary metabolites, i.e. atranorin (At), barbatic acid (Bar), fumarprotocetraric acid (Fum), grayanic acid (Gra), merochlorophaeic acid (Mer), perlatolic acid (Per), squamatic acid (Sq), thamnolic acid (Thm), usnic acid (Us), and zeorin (Zeo), as constrained by soil features (silt/clay, sand (total, fine and coarse), gravel, organic matter, soil particle shape

(angular and rounded), and $\mathrm{pH}$ value). The secondary metabolites (didymic, gyrophoric, lobaric, norstictic, pinastric, salazinic, stictic, 
and vulpinic acids) were not found to be at significant levels in any of the five locations or were at frequencies $<20 \%$ and are not included in the figure. The first RDA axis accounts for $62.2 \%$ of the total variation and the second axis for $22.8 \%$ of the variation.

Figure 4. Redundancy analysis of sites and lichen species (see Table 5 for species abbreviations) constrained by soil features (silt/clay, sand (total, fine and coarse), gravel, organic matter, soil particle shape (angular and rounded), and pH value). The collection locations are abbreviated as in Fig. 3. The first RDA axis accounts for $44.81 \%$ and the second axis for $19.93 \%$ of the variation in the data. 


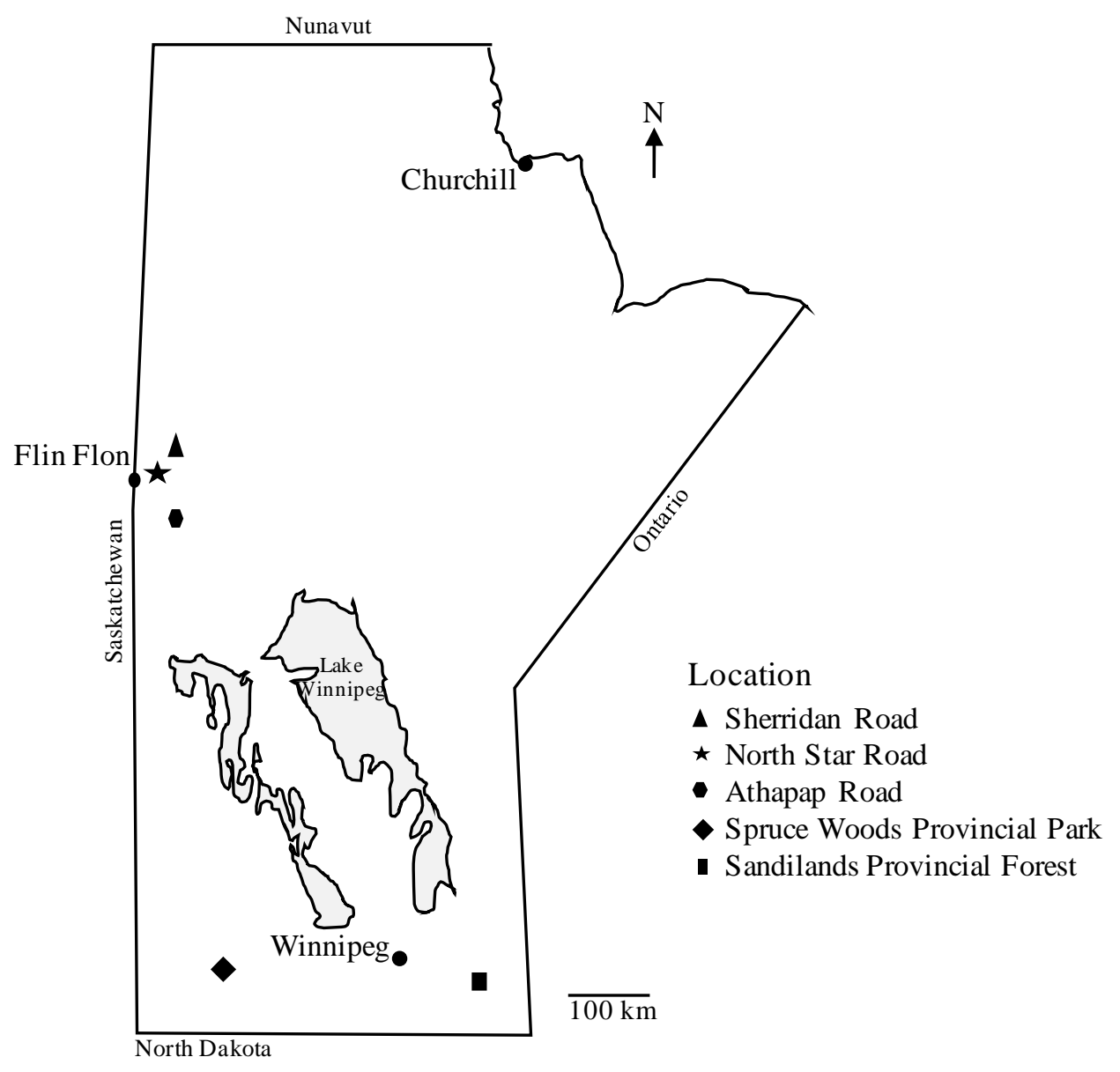

Figure 1 


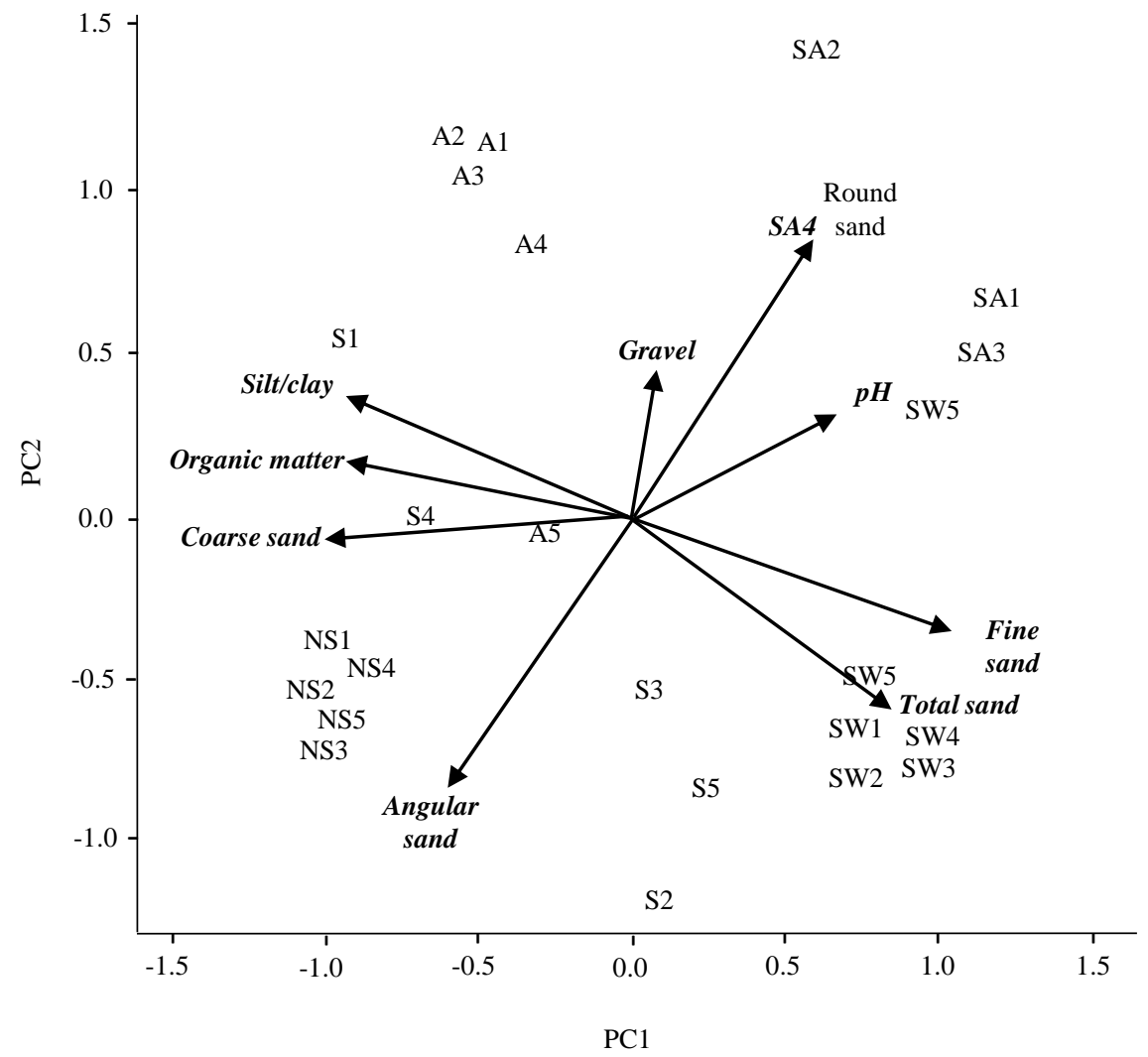

Figure 2 


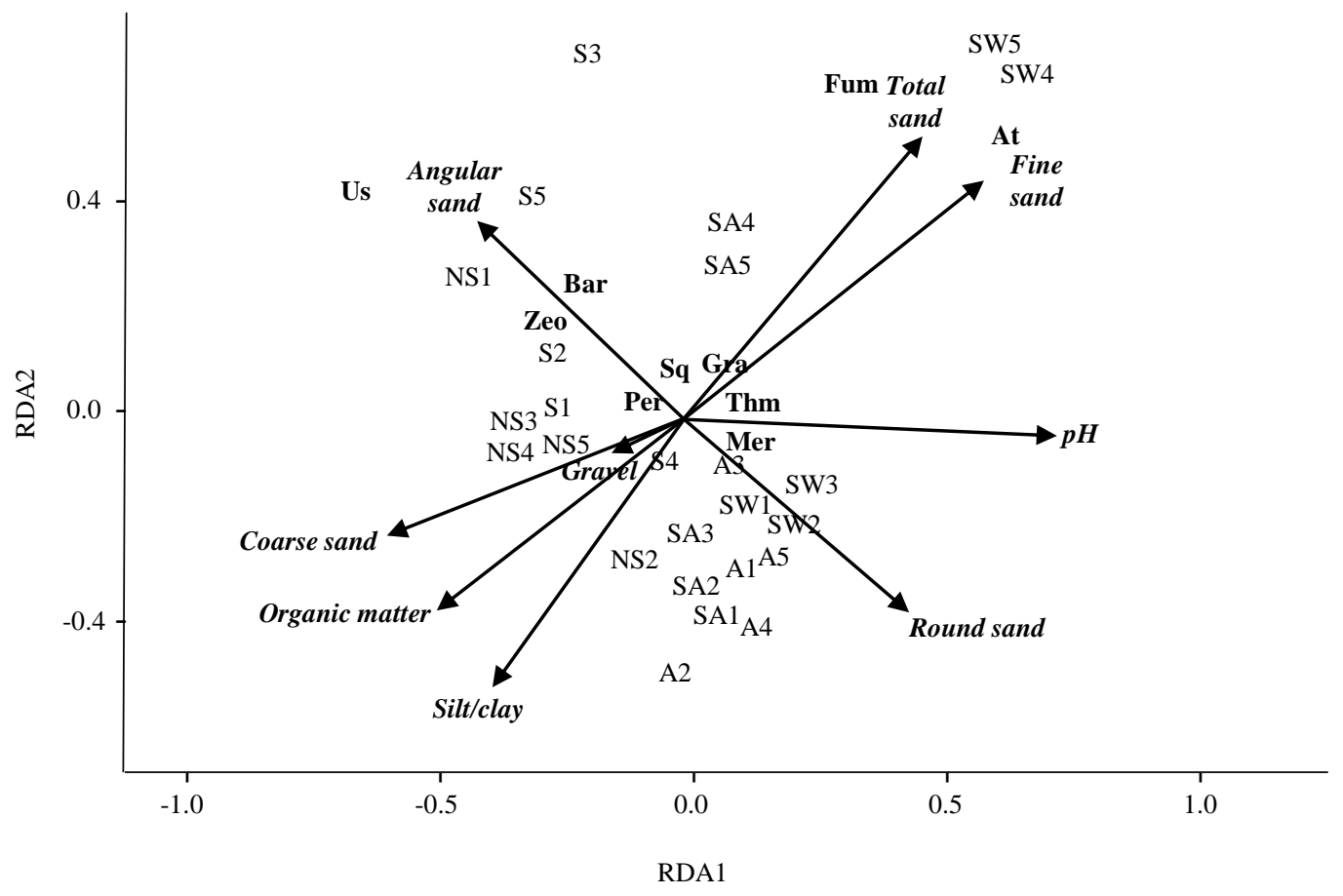

Figure 3 


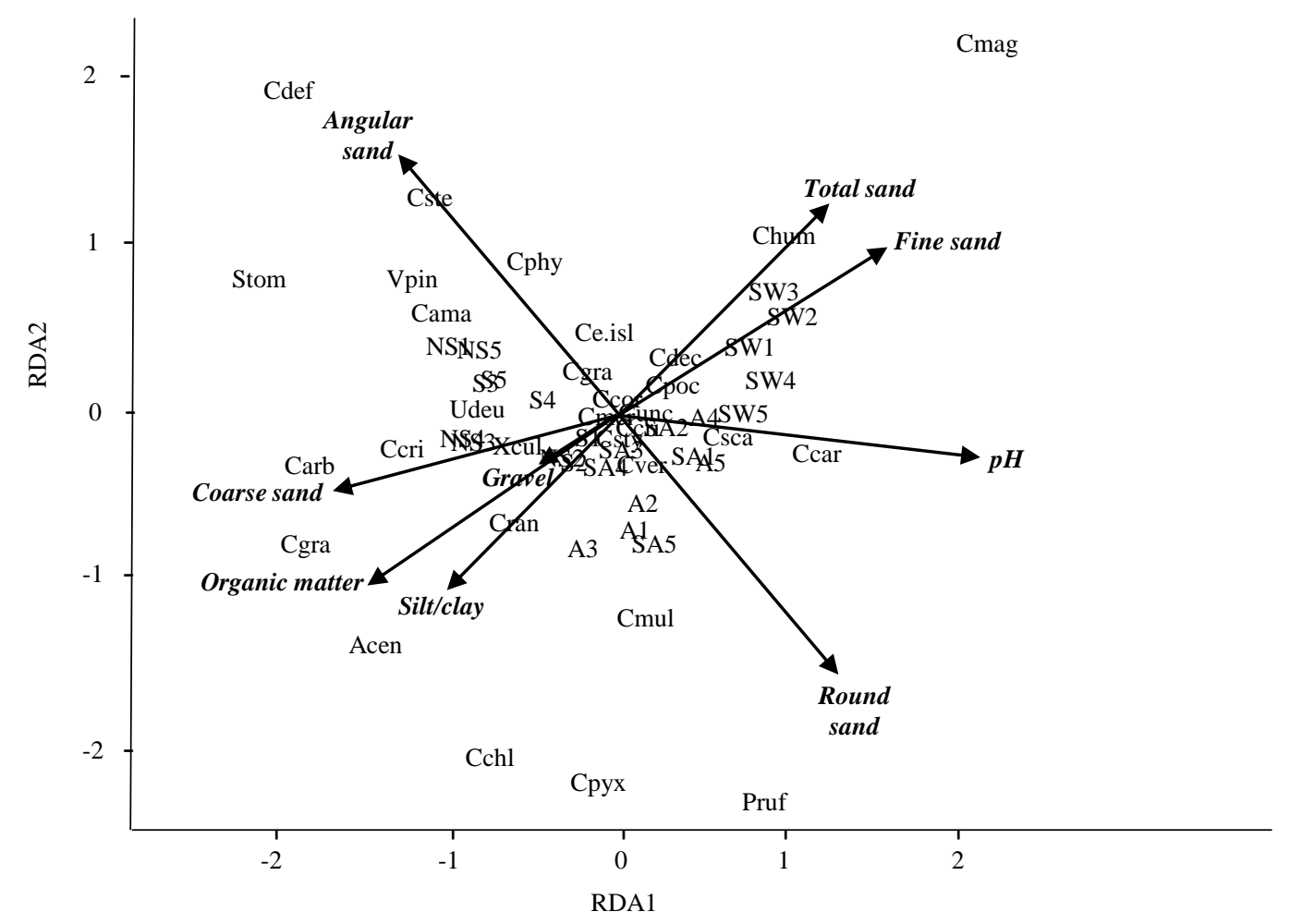

Figure 4 